\title{
KONVERGENSI PENDAPATAN \\ INDONESIA DAN MITRA REGIONAL TRADE AGREEMENT (ASEAN+6): APLIKASI METODE CLUSTER FUZZY
}

\section{Income Convergence on Indonesia and Regional Trade Agreement Partners (ASEAN+6): The Application of Fuzzy Clustering Method}

\author{
Azis Muslim \\ Pusat Kebijakan Perdagangan Luar Negeri, BP2KP, Kementerian Perdagangan-RI, \\ Jl. M.I. Ridwan Rais No.5 Jakarta Pusat, azis.muslim@kemendag.go.id \\ Naskah diterima: 6/1/2015 Naskah direvisi:9/2/2015 Disetujui diterbitkan: 10/4/2015
}

\begin{abstract}
Abstrak
Studi ini mengevaluasi pernyataan bahwa Regional Trade Agreement (RTA) mendorong konvergensi pendapatan. Dengan menggunakan data historis dan menerapkan algoritma fuzzy c-means clustering studi ini menguji konvergensi pendapatan Indonesia dan mitra RTA. Hasil studi menunjukkan bahwa dalam dua dasawarsa sejak tahun 1993, dengan adanya RTA, Indonesia mengalami pertumbuhan ekonomi, tetapi pendapatan Indonesia tidak konvergen ke arah pendapatan negara maju. Perdagangan perlu dipakai sebagai sarana alih pengetahuan dan teknologi serta peningkatan "kapabilitas sosial" untuk mendukung percepatan pertumbuhan ekonomi.
\end{abstract}

Kata kunci: Perdagangan, RTA, Pendapatan, Konvergensi, Fuzzy

\begin{abstract}
This study evaluates the proposition that Regional Trading Agreements (RTA) endorses convergence of income. Using historical data and fuzzy c-means clustering algorithm, this study analyzes the convergence of Indonesia's income and RTA partners. The results show that in two decades since 1993, with the presence of RTA, Indonesia has experienced economic growth, yet Indonesia's income did not converge towards the incomes of developed countries. Trade needs to be utilized as a mean to support knowledge and technology transfer and to increase "social capability" to enhance the acceleration of economic growth.
\end{abstract}

Keywords: Trade, RTA, Income, Convergence, Fuzzy

JEL Classification: F10, F15, C14, C22

\section{PENDAHULUAN}

Maraknya regionalisme di tahun 90-an menarik perhatian akademisi dan para ilmuwan untuk meneliti peran perjanjian perdagang regional (Regional Trade Agreement - RTA) terhadap ekonomi. Perjanjian perdagangan regional diharapkan dapat memberikan dampak positif terutama terhadap negara anggota perjanjian tersebut. Perdagangan diharapkan menjadi salah satu penghubung terjadinya limpahan teknologi dari negara maju ke negara berkembang. Lalu, tingkat pendapatan negara maju dan negara berkembang dalam jangka panjang diprediksi 
semakin konvergen (Charles, Darne, \& Hoarau, 2012).

Indonesia sebagai negara yang aktif dalam perdagangan dunia juga aktif dalam menjalin kerjasama perdagangan dan diikat dalam suatu perjanjian perdagangan. Secara formal ikatan perjanjian di tingkat ASEAN disepakati pada tanggal 1 Januari 1993 dalam bentuk perjanjian perdagangan bebas ASEAN (ASEAN Free Trade Agreement - AFTA). Dalam kerangka ASEAN Indonesia telah memperluas kerjasamanya dalam bentuk perjanjian regional dengan China, Korea, Jepang, India, Australia, dan Selandia Baru. Selain dalam kerangkaASEAN Indonesia juga melakukan kerjasama perdagangan bilateral dengan Jepang dalam kerangka Indonesia Japan Economic Partnership Agreement (IJEPA).

Indonesia sebagai negara berkembang tentunya dalam jangka panjang mengharapkan posisi perekonomiannya dapat sejajar dengan negara lain. Dilihat dari sisi sejarah sebelum krisis ekonomi Indonesia adalah salah satu kekuatan ekonomi regional ASEAN. Namun demikian, dampak krisis ekonomi yang terjadi menyebabkan posisi perekonomian Indonesia menurun. Upaya kerjasama perdagangan di tingkat regional dapat menjadi sarana untuk meningkatkan posisi perekonomian Indonesia. Dengan terbukanya perdagangan diharapkan dampak positif perdagangan yang berujung pada peningkatan pertumbuhan ekonomi Indonesia dapat dicapai. Perekonomian Indonesia diharapkan konvergen dengan perekonomian negara yang lebih maju.

Hal ini sejalan dengan model pertumbuhan neo-klasik yang memprediksi bahwa pendapatan per kapita/ output dari perekonomian akan konvergen pada level yang sama, tidak tergantung pada faktor capital endowment di awal periode. Artinya, suatu saat tingkat kemakmuran negaranegara maju dan negara-negara berkembang akan bertemu pada tingkat yang sama. Disebutkan pula bahwa akan terjadi catching up effect, yaitu negara-negara berkembang akan mampu mengejar negara-negara maju (Romer, 2011).

Selanjutnya, model pertumbuhan neo klasik mensyaratkan persamaan kondisi steady state antara dua ekonomi. Secara natural perekonomian yang lebih kecil stok kapitalnya akan tumbuh lebih cepat (Secara empiris hal ini dibuktikan dengan pertumbuhan ekonomi Jerman dan Jepang yang cepat setelah kekalahan mereka di perang dunia ke-2). Di lain pihak jika kondisi steady state-nya berbeda, yang disebabkan perbedaan rate of saving, maka konvergensi tidak dapat diharapkan.

Berlawanan dengan model pertumbuhan neo-klasik, model yang relatiflebih baru yaitu model pertumbuhan endogen memiliki feature yang berbeda dengan teori pertumbuhan neo-klasik (Romer, 2011). Pada model pertumbuhan yang baru ini dimungkinkan fungsi produksi tidak selalu konveks seperti asumsi pada model pertumbuhan neo-klasik. Keseimbangan yang berbeda pada kondisi jangka panjang juga dimungkinkan. Pandangan baru teori pertumbuhan ini juga tidak menyimpulkan adanya konvergensi pada perekonomian.

Jika dikaitkan dengan perdagangan internasional, kebijakan perdagangan secara langsung berpengaruh pada arus barang dan jasa diantara negaranegara yang melakukan perdagangan, dan kebijakan perdagangan bebas akan memicu konvergensi factor price antara negara tersebut. Walaupun demikian 
konvergensi factor price tidak selalu berakibatkonvergensidalam pendapatan. Walaupun liberalisasi perdagangan dan konvergensi pendapatan sama-sama terjadi hal ini tidaklah selalu membuktikan adanya hubungan kausalitas diantara keduanya (Bajona \& Kehoe, 2010).

Hubungan pendapatan dengan perdagangan dapat ditelusuri dari teori perdagangan Heckscher-OhlinSamuelson tentang faktor proporsi dimana perbedaan rasio modal dan tenaga kerja akan meningkatkan perdagangan. Perkembangan berikutnya Krugman (1979) dan Helpman (1981), dengan new trade theory, menunjukkan bahwa semakin konvergen pendapatan akan meningkatkan perdagangan antar negara-negara tersebut.

Pendapatan perkapita suatu negara (pcgdp) terdistribusi ke dalam dua faktor produksi yaitu tenaga kerja dan modal (Slaughter, 1998).

$$
\begin{gathered}
\text { pcgdp }=\frac{\text { Pendapatan Nasional }}{L}= \\
\frac{w L+r K}{L}=w+r \frac{K}{L}
\end{gathered}
$$

Dalam hal ini $L$ adalah jumlah tenaga kerja, $\mathrm{K}$ adalah modal, w adalah upah, sedangkan $r$ adalah bunga modal.

Harga dari faktor-faktor produksi (w dan r) merupakan penentu pendapatan nasional disamping kuantitas produksi dan teknologi. Teori mengenai factorprice-equalization (FPE) berimplikasi jika perdagangan bebas terjadi antara dua negara akan menuju keseimbangan maka bukan hanya akan terjadi persamaan harga barang-barang antara dua negara, namun akan menyebabkan persamaan dalam harga-harga faktor produksi (Slaughter, 1998).

Analog dengan teori FPE, Leamer \& Levinsohn (1995) membuat teori factor-price-convergence (FPC). Teori ini menyatakan bahwa menurunnya hambatan perdagangan akan menyebabkan konvergensi hargaharga faktor produksi. Liberalisasi perdagangan barang menyebabkan arus barang bergerak dengan mudah diantara negara yang terlibat dalam perdagangan, dan hal ini menyebabkan perbedaan antara harga-harga faktor produksi tereduksi.

Pengaruh perdagangan pada pendapatan berdasarkan analisa Grossman \& Helpman (1991) bahwa barang yang diperdagangkan memiliki kandungan pengetahuan dan teknologi. Dengan perdagangan, kandungan pengetahuan dan teknologi ini ditransfer antar negara. Hal lainnya dapat diterangkan dari adanya tekanan untuk meningkatkan kompetisi di pasar global. Dengan adanya tekanan kompetisi, perusahaan lokal harus meningkatkan produktifitasnya, yang pada akhirnya akan meningkatkan pendapatan tenaga kerja di industri lokal.

Secara empiris, hasil penelitian Sabaruddin (2014) menunjukkan bahwa liberalisasi berpengaruh positif terhadap masyarakat Indonesia. Penurunan tarif mengakibatkan naiknya pengeluaran rumah tangga rakyat Indonesia dan memicu efek pengali terhadap pendapatan kelompok rumah tangga lainnya. Meskipun pada kenyataannya pengeluaran terbesar terdapat pada golongan masyarakat perkotaan.

Achsani \& Siregar (2010) dengan menggunakan metode cluster fuzzy berkesimpulan bahwa negara-negara ASEAN+3 dapat dikelompokkan kedalam lima cluster dimana Singapura, Jepang, Korea dan RRT adalah sebagai pemimpin dalam hal ekonomi. Analisis juga dilengkapi perbedaan kondisi pada saat sebelum krisis, pada saat 
krisis, dan setelah krisis ekonomi 1997. Data yang diambil berdasarkan the Maastricht Treaty Criterion of the EU, yaitu rasio Hutang/GDP, rasio Budget Deficit/GDP, stabilitas nilai tukar, dan suku bunga.

Jayanthakumaran \& Lee (2013) mencoba membuktikan adanya konvergensi pendapatan untuk dua wilayah yaitu wilayah Association of South East Asian Nations (ASEAN) dan wilayah South Asian Association of Regional Cooperation (SAARC). Hasilnya menunjukkan bahwa untuk wilayah ASEAN yang terdiri dari negara Singapura, Malaysia, Thailand dan Indonesia secara konsisten memperlihatkan terjadinya konvergensi baik dalam hal pertumbuhan pendapatan maupun level pendapatan. Diperlihatkan juga bahwa untuk data ASEAN terdapat structural break yang diakibatkan krisis minyak sekitar tahun 1982 dan krisis ekonomi Asia 1997. Khusus untuk Indonesia ternyata setelah krisis mengalami divergensi.

Penelitian Li (2013) memperlihatkan bahwa konvergensi pendapatan wilayah ASEAN adalah lebih cepat dibanding wilayah Uni Eropa (EU) dan Perjanjian Perdagangan Bebas Amerika Utara (NAFTA) namun penelitian ini tidak membahas secara spesifik per negara ASEAN. Sementara itu, penelitian Jayanthakumaran \& Lee (2013) belum meneliti konvergensi pendapatan Indonesia dengan mitra dagang Indonesia terutama di luar ASEAN, padahal terdapat beberapa negara di luar ASEAN yang menjadi mitra dagang utama Indonesia. Penelitian ini mencoba mengisi kekosongan tersebut dengan mengemukakan topik tentang konvergensi pendapatan untuk kasus Indonesia dengan mitra dagangnya (ASEAN+6) yaitu: Malaysia, Singapura,
Thailand, Filipina, Brunei, Vietnam, Myanmar, Kamboja, Laos, Jepang, RRT, India, Korea Selatan, Selandia Baru, dan Australia

Dari literatur empiris ditemukan pula beberapa definisimengenai konvergensi, pemakaian beberapa alat statistik yang berbedadanhasil penelitianyang berbedabeda. Perlu dibedakan penelitian yang menghubungkan liberalisasi perdagangan dan konvergensi pendapatan serta penelitian yang menghubungkan antara derajat keterbukaan perdagangan dan konvergensi pendapatan. Penelitian empiris juga menunjukkan bahwa negara-negara miskin tidak tumbuh lebih cepat dibandingkan dengan negaranegara kaya. Hal tersebut memunculkan dugaan adanya perbedaan kondisi untuk beberapa negara sehingga timbul istilah konvergensi kondisional, dimana terjadi konvergensi untuk wilayah masing-masing (Schmitt \& Starke, 2011).

Studi ini menjawab pertanyaan apakah RTA mendorong konvergensi pendapatan untuk kasus Indonesia dengan mitra dagangnya (ASEAN+6). Fokus studi adalah pada konvergensi pendapatan Indonesia dengan mitra RTAnya dengan menggunakan metodologi analisis cluster fuzzy (Achsani \& Siregar, 2010; Boreiko, 2002; Stroomer \& Giles, 2003). Metode cluster fuzzy digunakan untuk mendapatkan manfaat pendekatan himpunan fuzzy dalam hal meng-kluster data, dimana himpunan fuzzy mampu mengklasifikasi data secara fleksibel (Stroomer \& Giles, 2003).

\section{METODE}

\section{Metode Analisis}

Terdapat beberapa metode yang dapat digunakan untuk menguji terdapatnya konvergensi, seperti uji unit root dalam penelitian Bernard and 
Durlauf (1996) atau metode cluster konvensional dalam penelitian Nahar and Inder (2002). Disamping metode-metode tersebut, pendekatan yang relatif baru adalah metode fuzzy clustering. Pada dasarnya metode ini meminimalkan varian atau ketidaksamaan dari anggotaanggota cluster (Achsani \& Siregar, 2010). Jadi, sebenarnya metode ini adalah pengembangan metode cluster konvensional dengan fleksibilitas pengklasifikasian data (Stroomer \& Giles, 2003).

\section{Himpunan Fuzzy}

Teori probabilitas pada kurun waktu abad ini memegang peranan penting untuk menjelaskan pengertian tentang ketidakpastian. Pada tahun 1965, Prof. Lotfi A. Zadeh dari Universitas California di Barkeley memperkenalkan konsep tentang himpunan fuzzy (fuzzy set = himpunan kabur) yang secara tidak langsung menyatakan bahwa selain pendekatan probabilitas, ketidakpastian dapat didekati dengan metode lain dalam hal ini konsep himpunan fuzzy (Wong \& Lai, 2011). Teori himpunan fuzzy merupakan kerangka matematis yang digunakan untuk merepresentasikan ketidakpastian, ketidakjelasan, ketidaktepatan, kekurang informasian dan kebenaran parsial.

Himpunan fuzzy merupakan perluasan dari himpunan klasik (crisp). Pada himpunan klasik ada dua keanggotaan yaitu $\mu \mathrm{A}(\mathrm{x})=1$ apabila $x$ merupakan anggota $A$ dan $\mu A(x)=0$ apabila $x$ bukan anggota $A$.

Berbeda dengan himpunan klasik himpunan fuzzy memperlakukan elemen dalam derajat keanggotaan. Sebagai contoh apakah harga beras Rp 10.000 tergolong mahal atau sedang-sedang saja? Dalam konsep himpunan fuzzy dan dalam dunia nyata "kedua pernyataan tersebut benar" dan mungkin sebagai jawaban.

Gambar 1 memperlihatkan representasi harga beras dalam himpunan konvensional dan himpunan fuzzy. Dalam himpunan klasik harga beras Rp 10.001 akan diklasifikasikan sebagai mahal sedangkan harga Rp 9.999 di klasifikasikansebagaisedang. Perubahan kecil dalam sistem dapat menyebabkan perbedaan reaksi yang berarti. Dalam himpunan fuzzy, perubahan kecil harga beras akan memberikan hasil perubahan yang tidak jelas pada kinerja sistem.

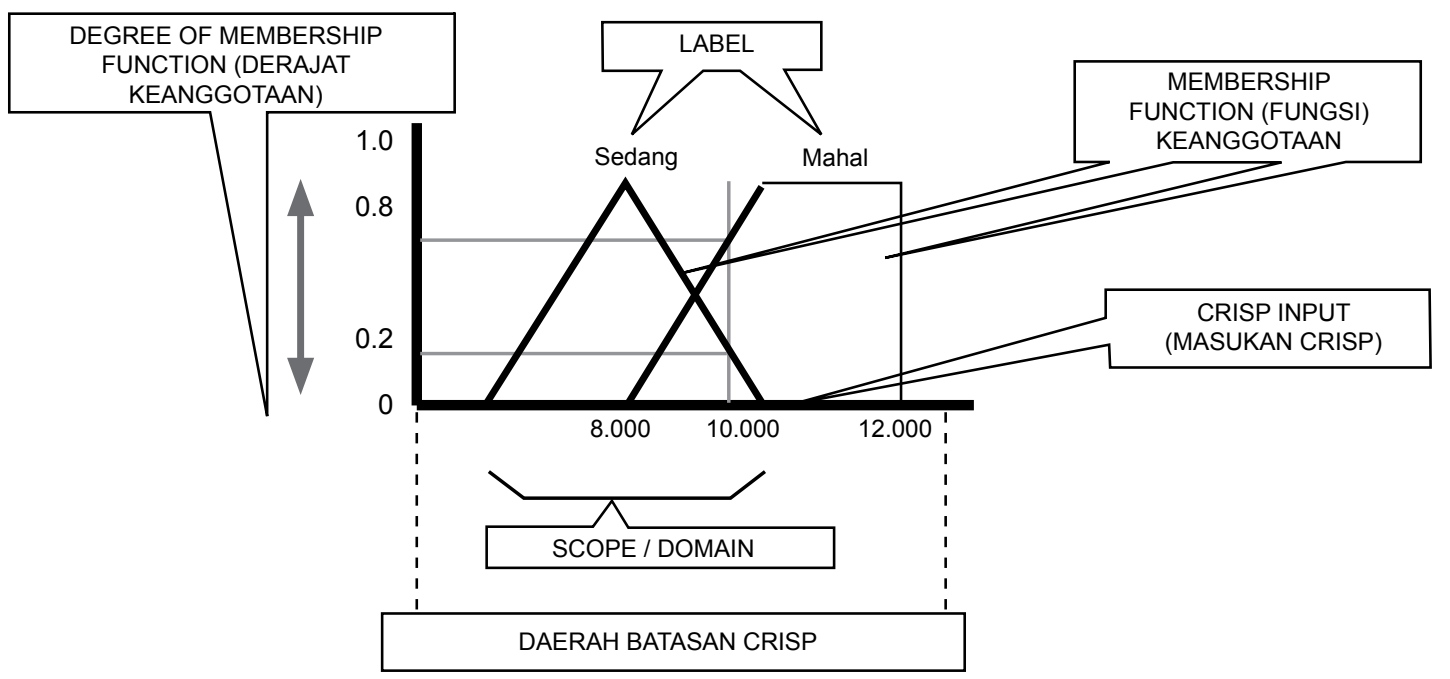

Sumber: Muslim \& Ekananda (2007)

\section{Gambar 1. Fungsi Keanggotaan Fuzzy}


Derajat Keanggotaan adalah kompatibilitas crisp dengan fungsi keanggotaan (dari 0 sampai 1). Label adalah nama yang digunakan untuk mengidentifikasi fungsi keanggotaan. Fungsi keanggotaan adalah definisi himpunan fuzzy dengan memetakan masukan crisp dari domainnya ke derajat keanggotaan. Masukan Crisp adalah masukan yang tegas dan tertentu.

Ada dua cara mendefinisikan keanggotaan himpunan fuzzy, yaitu secara numeris dan fungsional. Definisi numeris menyatakan fungsi derajat keanggotaan sebagai vektor jumlah yang tergantung pada tingkat diskretisasi. Misalnya, jumlah elemen diskret dalam semesta pembicaraan. Definisi fungsional menyatakan derajat keanggotaan sebagai batasan ekspresi analitis yang dapat dihitung. Standar atau ukuran tertentu pada fungsi keanggotaan secara umum berdasar atas semesta $X$ bilangan real. Fungsi keanggotaan (membership-function) yang digunakan pada penelitian ini adalah fungsi keanggotaan generalized bell (gbelll membership function) dimana persamaan fungsi ini adalah :

$$
G(x ; a, b, c)=\frac{1}{1+\left|\frac{x-c}{a}\right|^{2 b}}
$$

Gambar keanggotaannya adalah :

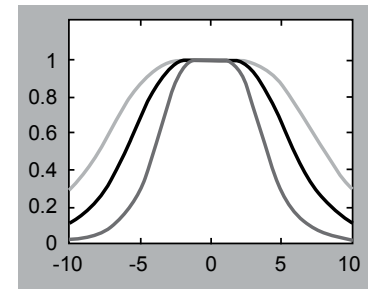

(a)

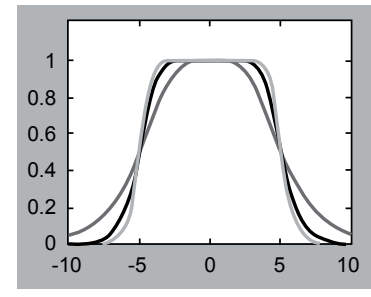

(b)

fungsi

\section{Fuzzy Clustering}

Pada algoritma cluster fuzzy yang akan digunakan perlu digambarkan terlebih dahulu tentang konsep partisi sample data kepada beberapa cluster. Pada proses peng-cluster-an secara klasik, pembentukan partisi dilakukan sedemikian rupa sehingga setiap objek berada tepat pada satu partisi. Pada beberapa situasi, fuzzy clustering, lebih alami daripada clustering klasik sebab adakalanya kita tidak bisa mendefinisikan suatu nilai tepat di satu partisi karena sebenarnya mungkin terletak pada dua partisi.

Pada logika fuzzy ada beberapa metode untuk melakukan clustering data, namun disini akan dibahas salah satunya yaitu fuzzy C-Means (FCM). FCM adalah metode pengklusteran data dimana keberadaan tiap data dalam cluster ditentukan oleh nilai keanggotaannya. Suatu algoritma dikatakan fuzzy clustering jika dan hanya jika algoritma tersebut menggunakan parameter strategi adaptif secara softcompetitive (non-crisp) (Izakian \& Abraham, 2011).

Pada kondisi awal pusat cluster ditentukan lalu diperbaiki secara berulang sehingga pusat cluster akan bergerak menuju suatu lokasi yang tepat. Perulangan ini didasarkan minimisasi fungsi obyektif pada halaman berikut:

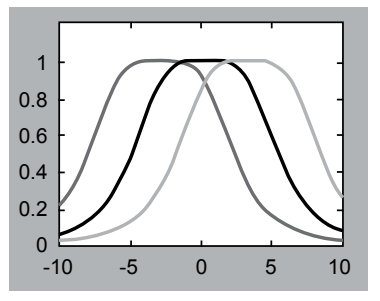

(c)

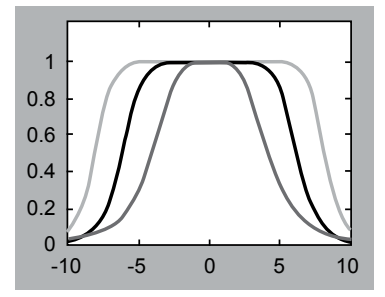

(d)

Gambar 2. Grafik Fungsi Keanggotaan Gbell

Keterangan : (a) merubah parameter a, (b) merubah parameter b, (c) merubah parameter c, (d) merubah parameter b dan c

Sumber : Tapia-Herrera et al., (2013) 


$$
J_{w}(U, V ; X)=\sum_{k=1}^{n} \sum_{i=1}^{C}\left(\mu_{i k}\right)^{w}\left(d_{i k}\right)^{2}
$$

Namun tidak ada penjelasan detil mengenai pemilihan bobot " $w$ " yang nilainya antara 1 sampai tak terhingga, dalam praktek biasanya dipilih $\mathrm{w}=2$ sedangkan dalam kasus crisp maka $w=1$. $U$ adalah matrik random partisi fuzzy dari $X$ (data yang akan di-cluster) menjadi c kelompok, sedangkan $\mathrm{V}$ adalah matrik pusat cluster.

$d_{i k}=d\left(x_{k}-v_{i}\right)=\left[\sum_{j=1}^{n}\left(x_{k j}-v_{i j}\right)\right]^{\frac{1}{2}}$

Vi adalah pusat clusternya.

$X=\left[\begin{array}{ccc}x_{11} & \cdots & x_{1 m} \\ \vdots & & \vdots \\ x_{n 1} & \cdots & x_{n m}\end{array}\right]$

$$
V=\left[\begin{array}{ccc}
x_{1} & \cdots & x_{1 m} \\
\vdots & & \vdots \\
x_{C 1} & \cdots & x_{C m}
\end{array}\right]
$$

Nilai $\mathrm{J}$ terkecil adalah yang terbaik, sehingga :

$$
J_{w}^{*}\left(U^{*}, V^{*} ; X\right)=\min J(U, V ; X)
$$

\section{Teorema 1.}

Jika $d_{i k}>0, \forall i, k ; w>1$, dan $X$ setidaknya memiliki c elemen, maka $(U, V)$ dapat meminimisasi $J_{w}$ hanya jika :

$$
\mu_{i k}=\left[\sum_{j=1}^{C}\left(\frac{d_{i k}}{d_{j k}}\right)^{\frac{2}{w-1}}\right]^{-1} ; 1 \leq \mathrm{i} \leq \mathrm{C} ; 1 \leq \mathrm{k} \leq \mathrm{n} . \text { Dan }
$$

$$
v_{i j}=\frac{\sum_{j=1}^{n}\left(\mu_{i k}\right)^{w} \cdot x_{k j}}{\sum_{j=1}^{n}\left(\mu_{i k}\right)^{w}} ; 1 \leq \mathrm{i} \leq \mathrm{C} ; 1 \leq \mathrm{j} \leq \mathrm{m} .
$$

Secara umum algoritma FCM akan mengikuti tahapan berikut (Izakian \& Abraham, 2011; Zimmermann, 2010) :

1. Tentukan :

i. Matriks $X$ berukuran $\mathrm{n} \times \mathrm{m}$, dengan $\mathrm{n}=$ jumlah data yang akan di-cluster; dengan $\mathrm{m}=$ jumlah variabel.

ii. Jumlah cluster yang akan dibentuk $=\mathrm{C} \geq 2$.

iii. Pangkat (pembobot) $=\mathrm{w}$ biasanya 2 .

iv. Maksimum iterasi.

v. Kriteria penghentian $=\xi$ (nilai positif yang sangat kecil)

vi. Iterasi awal, $\mathrm{t}=1$, dan $\Delta=1$;

2. Bentuk matriks partisi awal, $U^{\circ}$, sebagai berikut:

$U=\left[\begin{array}{cccc}\mu_{11}\left(x_{1}\right) & \mu_{12}\left(x_{2}\right) & \cdots & \mu_{1 n}\left(x_{n}\right) \\ \mu_{21}\left(x_{1}\right) & \mu_{2}\left(x_{2}\right) & \cdots & \mu_{2 n}\left(x_{n}\right) \\ \vdots & \vdots & & \vdots \\ \mu_{C 1}\left(x_{1}\right) & \mu_{C 2}\left(x_{2}\right) & \cdots & \mu_{C n}\left(x_{n}\right)\end{array}\right]$

Matriks partisi awal biasanya dipilih secara acak.

3. Hitung pusat cluster, $\mathrm{V}$, untuk setiap cluster:

$$
v_{i j}=\frac{\sum_{j=1}^{n}\left(\mu_{i k}\right)^{w} \cdot x_{k j}}{\sum_{j=1}^{n}\left(\mu_{i k}\right)^{w}}
$$

4. Perbaiki derajat keanggotaan setiap data pada setiap cluster (perbaiki matriks partisi), sebagai berikut: 
$\mu_{i k}=\left[\sum_{j=1}^{C}\left(\frac{d_{i k}}{d_{j k}}\right)^{\frac{2}{w-1}}\right]^{-1}$

Dengan :

$d_{i k}=d\left(x_{k}-v_{i}\right)=\left[\sum_{j=1}^{n}\left(x_{k j}-v_{i j}\right)\right]^{\frac{1}{2}}$

5. Tentukan kriteria berhenti, yaitu perubahan matriks partisi pada iterasi sekarang dengan iterasi sebelumnya, sebagai berikut:

$\Delta=\left\|U^{t}-U^{t-1}\right\|$

Apabila $\Delta \leq \xi$, maka iterasi dihentikan, namun apabila $\Delta>\xi$, naikkan iterasi $(\mathrm{t}=$ $\mathrm{t}+1$ ) dan kembali ke langkah 3 .

\section{Data}

Data yang digunakan untuk kajian ini berasal dari International Financial Statistics (IFS) - IMF berupa data GDP per kapita, yang berdasarkan Purchasing
Power Parity (PPP), untuk Indonesia dan negara mitra RTA yaitu: Malaysia, Singapura, Thailand, Filipina, Brunei, Vietnam, Myanmar, Kamboja, Laos, Jepang, RRT, India, Korea Selatan, Selandia Baru, dan Australia. Data yang digunakan adalah data tahunan dengan periode dari tahun 1990 sampai 2013.

\section{HASIL DAN PEMBAHASAN}

Data GDP per kapita Indonesia dan mitra dagang terpilih di atas diolah dengan Matlab R2008e untuk mendapatkan pengelompokkan berdasarkan cluster fuzzy (Hasil pengolahan diperlihatkan pada Gambar 3). Cluster pertama digambarkan dalam bentuk kurva berwarna merah mewakili cluster kelompok GDP per kapita rendah. Cluster kedua digambarkan dalam bentuk kurva berwarna biru mewakili cluster kelompok GDP per kapita sedang. Cluster ketiga digambarkan dalam bentuk kurva berwarna hijau mewakili cluster kelompok GDP per kapita tinggi.

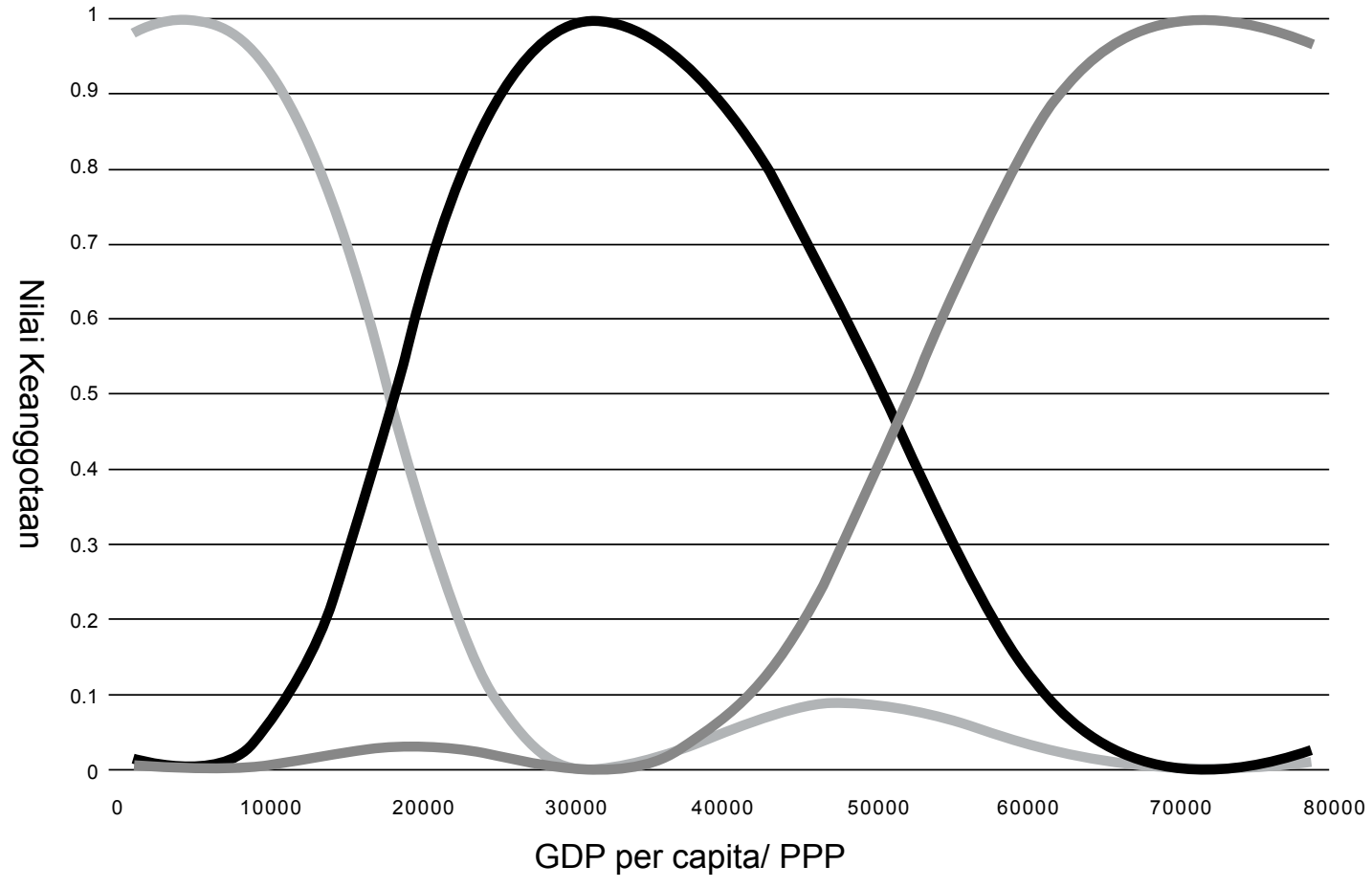

Gambar 3. Fungsi Keanggotaan Fuzzy 
Nilai GDP per kapita 10.000 digunakan sebagai contoh untuk membaca fungsi keanggotaan fuzzy dari Gambar 3. Apabila digunakan konsep himpunan konvensional (himpunan crisp) GDP per kapita 10.000 secara tegas merupakan bagian dari himpunan berpendapatan rendah, namun untuk himpunan fuzzy GDP per kapita 10.000 direpresentasikan ke dalam himpunan berpendapatan rendah, sedang, dan tinggi dengan derajat keanggotaan yang berbeda-beda. Dalam himpunan fuzzy GDP perkapita 10.000 direpresentasikan menjadi $(0,91 ; 0,08 ; 0,01)$ artinya walaupun masih dominan di himpunan berpendapatan rendah, namun masih memiliki keanggotaan di himpunan lainnya.

Clusterfuzzy yang dibuat pada proses sebelumnya digunakan untuk melihat perkembangan GDP per kapita masingmasing negara seperti yang diperlihatkan pada Tabel 1 di bawah ini. Secara keseluruhan pengelompokan negara relatif tidak mengalami perubahan. Hanya Korea Selatan, Malaysia, dan Singapura yang berubah pengelompokkannya menjadi lebih tinggi. Singapura berubah dari negara berpendapatan sedang menjadi berpendapatan tinggi. Korea Selatan dan Malaysia berubah dari negara berpendapatan rendah menjadi berpendapatan sedang.

Tabel 1. Cluster Fuzzy Negara Mitra Dagang Indonesia di tahun 1993, 2003, dan 2013

\begin{tabular}{|l|c|c|c|c|c|c|c|c|c|}
\hline \multicolumn{1}{|c|}{ Negara } & \multicolumn{3}{|c|}{1993} & \multicolumn{3}{|c|}{2003} & \multicolumn{3}{|c|}{2013} \\
\hline Australia & I & II & III & I & II & III & I & II & III \\
Brunei Darussalam & 0.01 & 0.99 & 0.00 & 0.03 & 0.95 & 0.03 & 0.07 & 0.79 & 0.14 \\
Kamboja & 0.01 & 0.01 & 0.98 & 0.01 & 0.01 & 0.98 & 0.00 & 0.00 & 1.00 \\
RRT & 0.98 & 0.01 & 0.00 & 0.99 & 0.01 & 0.00 & 1.00 & 0.00 & 0.00 \\
India & 0.99 & 0.01 & 0.00 & 1.00 & 0.00 & 0.00 & 0.84 & 0.14 & 0.01 \\
Indonesia & 0.99 & 0.01 & 0.00 & 1.00 & 0.00 & 0.00 & 1.00 & 0.00 & 0.00 \\
Jepang & 1.00 & 0.00 & 0.00 & 1.00 & 0.00 & 0.00 & 0.95 & 0.04 & 0.01 \\
Rep. Korea & 0.00 & 1.00 & 0.00 & 0.00 & 1.00 & 0.00 & 0.02 & 0.97 & 0.01 \\
Lao PDR & 0.73 & 0.25 & 0.02 & 0.14 & 0.84 & 0.02 & 0.00 & 1.00 & 0.00 \\
Malaysia & 0.99 & 0.01 & 0.00 & 1.00 & 0.00 & 0.00 & 1.00 & 0.00 & 0.00 \\
New Zealand & 0.84 & 0.14 & 0.01 & 0.59 & 0.39 & 0.03 & 0.17 & 0.81 & 0.02 \\
Filipina & 0.16 & 0.81 & 0.02 & 0.00 & 0.99 & 0.00 & 0.00 & 1.00 & 0.00 \\
Singapura & 1.00 & 0.00 & 0.00 & 1.00 & 0.00 & 0.00 & 0.99 & 0.01 & 0.00 \\
Vietnam & 0.05 & 0.88 & 0.07 & 0.07 & 0.33 & 0.60 & 0.00 & 0.01 & 0.98 \\
\hline
\end{tabular}

Dengan argumentasi adanya konvergensi kondisional (Schmitt \& Starke, 2011), dimana terjadikonvergensi untuk kondisi tertentu, kelompok negara berpendapatan rendah (kelompok I) yang merupakan hasil pengelompokkan di Gambar 3 dikelompokan lagi secara tersendiri. Dalam proses ini hanya negara Kamboja, RRT, India, Indonesia, Laos, Filipina, dan Vietnam yang diolah.

Hasil pengolahan diperlihatkan pada Gambar 4 yaitu kurva fungsi keanggotaan fuzzy untuk negara berpendapatan rendah hasil pengelompokkan di Gambar 3. Cluster pertama digambarkan dalam bentuk kurva berwarna merah mewakili clusterkelompok GDP per kapita rendah. Cluster kedua digambarkan dalam bentuk kurva berwarna biru mewakili cluster kelompok GDP per kapita sedang. Cluster ketiga digambarkan dalam bentuk kurva berwarna hijau mewakili cluster kelompok GDP per kapita. 


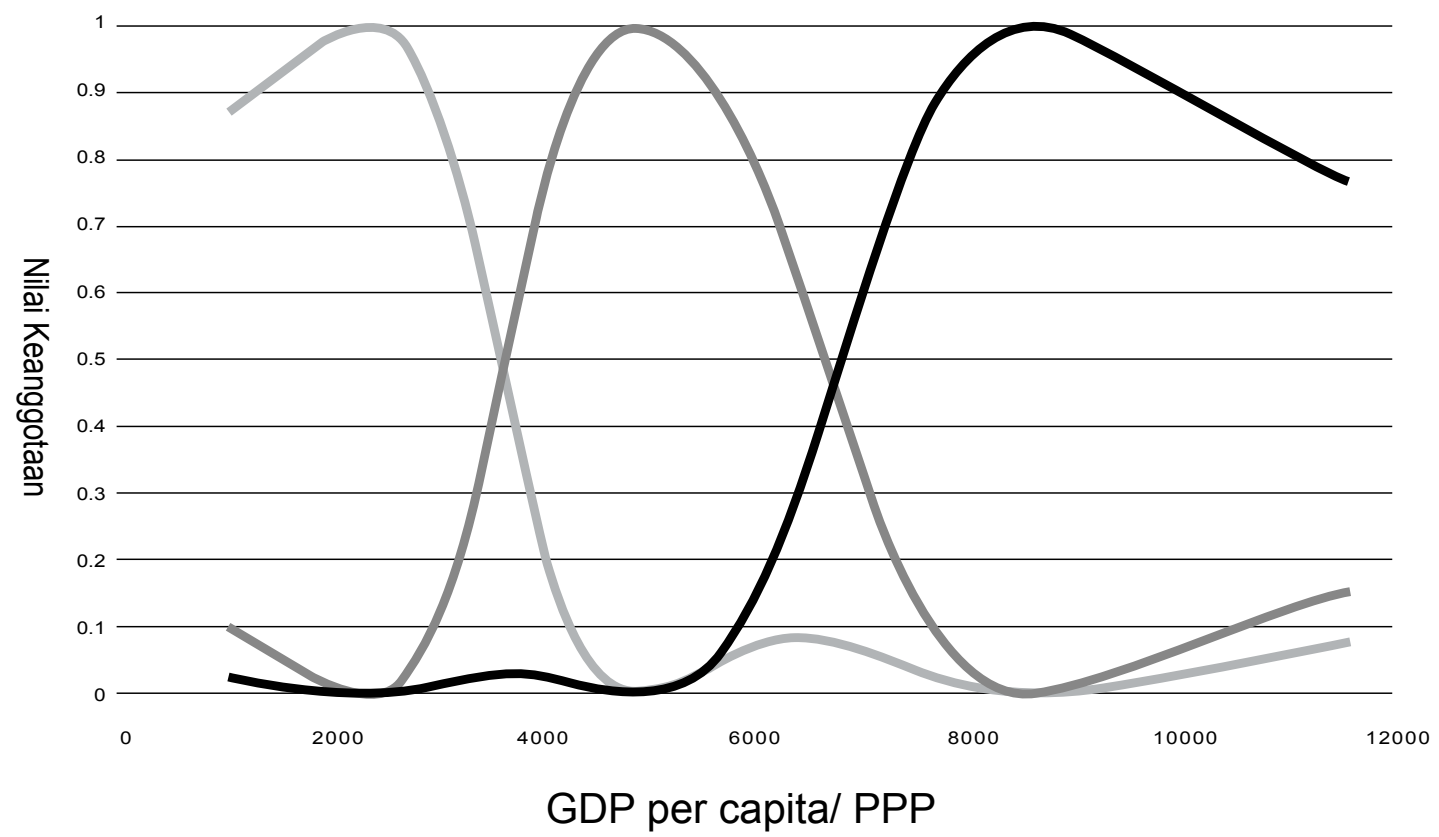

Gambar 4. Fungsi Keanggotaan Fuzzy

Seperti pada proses sebelumnya keanggotaan fungsi himpunan seperti setiap negara ditampilkan yang diperlihatkan pada Tabel 2 di perkembangannya dalam bentuk bawah ini.

Tabel 2. Cluster Fuzzy Negara Mitra Dagang Indonesia di tahun 1993, 2003, dan 2013

\begin{tabular}{|c|c|c|c|c|c|c|c|c|c|}
\hline & \multicolumn{3}{|c|}{1993} & \multicolumn{3}{|c|}{2003} & \multicolumn{3}{|c|}{2013} \\
\hline & I & II & III & I & II & III & 1 & II & III \\
\hline RRT & 0,98 & 0,02 & 0,00 & 0,01 & 0,99 & 0,00 & 0,08 & 0,15 & 0,77 \\
\hline Filipina & 0,31 & 0,66 & 0,03 & 0,03 & 0,96 & 0,01 & 0,09 & 0,67 & 0,25 \\
\hline India & 0,98 & 0,02 & 0,00 & 0,90 & 0,09 & 0,01 & 0,02 & 0,97 & 0,01 \\
\hline Laos & 0,96 & 0,03 & 0,01 & 0,97 & 0,03 & 0,00 & 0,01 & 0,99 & 0,00 \\
\hline Kamboja & 0,87 & 0,10 & 0,03 & 0,95 & 0,04 & 0,01 & 0,88 & 0,10 & 0,01 \\
\hline
\end{tabular}

Tabel 2 memperlihatkan bahwa pada tahun 2013 Indonesia dan RRT, dalam hal pendapatan per kapita, menduduki kelas teratas diantara 5 (lima) negara lainnya (Filipina, India, Vietnam, Laos, dan Kamboja). Apabila dilihat dalam dua dasawarsa setelah tahun 1993 Indonesia mengalami peningkatan kelas ekonomi dari kelas ekonomi II di tahun 1993 menjadi ekonomi III di tahun 2013.

Seperti Indonesia, demikian pula dengan RRT, yang mengalami peningkatan kelas, yaitu dari kelas ekonomi I di tahun 1993 menjadi ekonomi III di tahun 2013. Artinya, kecepatan pertumbuhan kelas pendapatan di RRT lebih cepat dibandingkan Indonesia.

Peningkatan kelas GDP per kapita Indonesia mengindikasikan bahwa telah terjadi pertumbuhan ekonomi, walaupun tidak terjadi konvergensi pendapatan Indonesia ke pendapatan negara mitra dagang. Pertumbuhan ekonomi Indonesia dibuktikan dengan 
adanya peningkatan kelas ekonomi dari kelas ekonomi II di tahun 1993 menjadi ekonomi III di tahun 2013 dalam kelompok negara Kamboja, RRT, India, Indonesia, Laos, Filipina, dan Vietnam seperti yang diolah pada Tabel 2 . Walaupun sebelumnya telah dibuktikan bahwa dalam kelompok ASEAN+6, kelas ekonomi Indonesia tetap tidak berubah masih di kelas ekonomi I pada tahun 1993, 2003, sampai 2013 seperti yang diperlihatkan pada Tabel 1. Hal tersebut membuktikan tidak terjadi konvergensi pendapatan Indonesia ke pendapatan Negara-negara ASEAN+6. Hasil ini sejalan dengan penelitian Jayanthakumaran \& Lee (2013) yang menyatakan bahwa khusus untuk kasus Indonesia ternyata setelah krisis Indonesia mengalami divergensi dengan ASEAN.

Dalam penelitian ini diperlihatkan bahwa untuk data pendapatan per kapita (berdasarkan PPP) Indonesia selama 20 tahun (1993-2013) tidak konvergen dengan mitra dagang. Hasil lainnya memperlihatkan bahwa dalam dua dasawarsa setelah tahun 1993 Indonesia mengalami peningkatan kelas ekonomi ataumemilikipertumbuhan ekonomiyang relatif lebih baik dibandingkan kelompok tertentu (Filipina, India, Vietnam, Laos, dan Kamboja). Secara keseluruhan hasil penelitian menunjukkan bahwa walaupun Indonesia tidak mencapai konvergensi dengan mitra dagang, yaitu: Malaysia, Singapura, Thailand, Filipina, Brunei, Vietnam, Myanmar, Kamboja, Laos, Jepang, RRT, India, Korea Selatan, Selandia Baru, dan Australia namun mampu mendapatkan manfaat pertumbuhan ekonomi.

Konvergensi pendapatan tentu diharapkan oleh negara-negara berkembang untuk mengejar persamaan pendapatan dengan negara maju.
Apabila hal ini dapat tercapai secara tidak langsung kesejahteraan masyarakat di negara berkembang menyamai negaranegara maju.

Teori ekonomi mengenai pertumbuhan yang diungkapkan oleh Solow mengenai teori pertumbuhan neoklasik memprediksi bahwa pendapatan per kapita/ output dari perekonomian akan konvergen, namun hal tersebut tidak selalu terealisasi pada dunia nyata. Walaupun, Jepang dan Jerman telah memperlihatkan kemampuan mereka mengejar ketertinggalan di bidang pembangunan dengan cepat, namun di belahan dunia lain banyak negaranegara terbelakang yang sulit untuk mengejar ketertinggalannya dari negara maju.

Demikian juga dengan Indonesia yang memiliki sejarah panjang dalam hal usaha mencapai pertumbuhan ekonomi yang diharapkan. Pada tahap awalnya Indonesia memiliki kesempatan menjadi salah satu macan Asia dikarenakan nilai pertumbuhan ekonomi yang cukup tinggi namun krisis Asia di tahun 1998 telah mengakibatkan pertumbuhan ini terhambat dan perlu mengumpulkan energi kembali untuk bisa bangkit dari keterpurukan.

Salah satu upaya untuk mendongkrak pertumbuhan ekonomi adalah keterlibatan Indonesia dalam perdagangan dunia. Dukungan terhadap keikutsertaan Indonesia dalam perdagangan dunia juga diwujudkan dengan menjadi anggota beberapa lembaga perdagangan tingkat dunia, multilateral, maupun bilateral serta menjadi bagian dari kerjasama dan kesepakatan ekonomi dan perdagangan global.

Terlepasnya Indonesia dari krisis ekonomi 1998 bukan berarti Indonesia telah terlepas dari kendala pertumbuhan 
ekonomi. Dikarenakan telah tergabung dalam jaringan ekonomi global, bukan hanya kendala faktor internal namun kendala faktor eksternal juga punya pengaruh dalam menghambat pertumbuhan.

Saat ini Indonesia menghadapi beberapa kendala yang diakibatkan faktoreksternal. Pertama, Perekonomian RRT yang memiliki kecenderungan melambat saat ini mengakibatkan permintaan domestik RRT berpengaruh terhadap ekspor negara mitra dagang RRT. RRT merupakan salah satu negara tujuan ekspor utama Indonesia, menurunnya permintaan RRT akan mengkoreksi peningkatan ekspor ke negara tersebut. Perekonomian di kawasan Eropa yang sampai saat ini belum pulih, isu quantitative easing USA, partisipasi Indonesia yang rendah dalam Global Production Network, dan resiko kawasan (Thailand political risk) adalah beberapa isu eksternal yang saat ini merupakan kendala bagi pencapaian target pertumbuhan ekonomi Indonesia.

Disamping faktor eksternal Indonesia juga memiliki kendala di dalam negeriyang perlu diatasi. Beberapa kendala internal tersebut diantaranya: stabilitas dan volatilitas Rupiah, kapasitas dan fasilitas logistik, daya saing dan produktivitas masih rendah, fasilitas perdagangan masih kurang, biaya ekonomi tinggi, dan infrastruktur yang belum memadai (Bank Indonesia, 2014).

Hasil studi yang dilakukan oleh Sjoholm (1999) untuk data Indonesia menunjukkan bahwa faktor knowledge spillover untuk level regional Indonesia kurang mendukung pertumbuhan ekonomi. Teori pertumbuhan sendiri menekankan bahwa faktor knowledge spillover tersebut memiliki pengaruh penting terhadap pertumbuhan. Knowledge spilloveradalah sarana untuk bisa mengejar ketertinggalan negara berkembang dari negara maju. Dengan knowledge spillover kemampuan teknologi dari negara maju akhirnya dapat dikuasai negara berkembang dan hal ini terjadi misalnya pada negara Jepang, Korea Selatan, serta RRT yang telah membuktikan kemampuannya menjadi negara maju.

Berkaca dari suksesnya negara Jepang, Korea Selatan, serta RRT dalam transformasi teknologi dan industri sebagai realisasi knowledge spillover perlu kebijakan yang mampu merealisasikan alih pengetahuan dan teknologi dari negara maju ke Indonesia. Dikaitkan dengan kerjasama perdagangan usaha alih teknologi ini perlu diupayakan sebagai hasil manfaat perdagangan. Perdagangan baik ekspor maupun impor merupakan bagian dari channel yang dilalui oleh terjadinya alih pengetahuan dan teknologi disamping FDI, patent, dan kedekatan geografis (Ang \& Madsen, 2013).

Abramovitz (1986) menambahkan komponen lain dari potensi untuk melakukan catch-up terhadap negara maju yaitu komponen "kapabilitas sosial" yaitu 'kompetensi teknis, dimana pendidikan, stabilitaas politik, perdagangan, industri, institusi, keuangan, dan lain sebagainya mungkin menjadi proxy'. Jika gap teknologi adalah faktor eksternal maka kapabilitas sosial adalah faktor internal. 'potensial total' ditentukan oleh kombinasi antara 'gap teknologi' dan 'kapabilitas sosial'. Dalam hal ini kualifikasi dari hipotesis catch-up adalah: 'Potensi negara untuk tumbuh cepat adalah kuat, tidak ditentukan hanya oleh ketertinggalannya (ketertinggalan teknologi) tapi digabung dengan kemajuan sosial'.

Mengikuti pendapat (Abramovitz, 1986), perdagangan adalah salah satu 
bagian dalam penguatan komponen "kapabilitas sosial". Artinya, untuk mencapai konvergensi pendapatan diperlukan komponen lainnya misalnya teknologi, pendidikan, industri, infrastruktur, institusi, keuangan, dan lain sebagainya. Dalam kasus Indonesia peningkatan volume dan nilai perdagangan serta keikutsertaan dalam kerjasama perdagangan global adalah salah satu unsur untuk melakukan catch-up terhadap negara maju. Untuk mencapai tujuan catch-up terhadap negara maju, komponen lainnya pun harus direalisasikan.

Krugman (1979) dan Helpman (1981) dalam the new trade theory justru menyatakan bahwa kesamaan pendapatan antar negara akan meningkatkan perdagangan antar negara-negara tersebut. Dalam pandangan teori ini perdagangan antar negara maju dengan negara maju atau negara berkembang dengan negara berkembang lebih dominan dilakukan. Hal ini menjadi tantangan tersendiri bagi negara bekembang untuk bisa mengcatch-up negara maju.

\section{KESIMPULAN DAN REKOMENDASI KEBIJAKAN}

Penelitian ini memperlihatkan bahwa data pendapatan per kapita (yang berdasarkan PPP) Indonesia selama 20 tahun (1993-2013) tidak konvergen terhadap mitra dagang. Akan tetapi, selama 20 tahun (1993-2013) Indonesia telah mengalami peningkatan kelas GDP per kapita, yang mengindikasikan bahwa, walaupun tidak terjadi konvergensi, namun manfaat berupa pertumbuhan ekonomi masih diperoleh.

Untuk kasus Indonesia dengan mitra dagangnya (ASEAN+6) perjanjian perdagangan regional belum dapat mendorong konvergensi pendapatan.
Selain itu, bukti empiris konvergensi menunjukkan bahwa pendapatan tidak dapat menjadi argumen dalam melakukan kerjasama regional di bidang perdagangan internasional.

Perlu kebijakan yang mampu merealisasikan alih pengetahuan dan teknologi sebagai knowledge spillover dari negara maju ke Indonesia. Alih pengetahuan dan teknologi ini perlu diupayakan sebagai manfaat dari dilakukannya kerjasama perdagangan. Perdagangan dipakai sebagai channel untuk alih pengetahuan dan teknologi.

Perdagangan juga menjadi salah satu komponen dalam mendukung meningkatnya "kapabilitas sosial" yaitu kompetensi teknis yang dimiliki negara untuk tumbuh dengan cepat dan kuat. Disamping perdagangan komponen lain yang mendukung meningkatnya "kapabilitas sosial" diantaranya: pendidikan, industri, infrastruktur, institusi, keuangan juga harus diperkuat.

Perdagangan perlu didukung perkembangannyadalamrangkamencapai pertumbuhan ekonomi dan peningkatan pendapatan masyarakat. Tujuan jangka panjang adalah meningkatkan kesejahteraan masyarakat, yang berkaitan pula dengan menyetarakan pendapatan dengan pendapatan negara maju. Kerjasama perdagangan di tingkat regional merupakan salah satu komponen penyokong pencapaian tujuan ini.

Dukungan terhadap keterlibatan Indonesia dalam kerjasama perdagangan global perlu ditingkatkan. Manfaat ekonomi yang ditunjukkan dengan peningkatan pertumbuhan ekonomi adalah keuntungan yang bisa didapat setelah bergabung dalam kerjasama perdagangan internasional. Dukungan lebih lanjut perlu didapatkan agar manfaat ini tidak hanya dalam hal pertumbuhan ekonomi namun juga 
percepatan pertumbuhan ekonomi sehingga Indonesia bisa setara dengan negara lain yang lebih maju.

\section{UCAPAN TERIMAKASIH}

Pada kesempatan ini ijinkanlah penulis memberikan ucapan terimakasih untuk Pihak-pihak yang membantu terwujudnya tulisan ini. Kepada Kepala Pusat Pengkajian Perdagangan Luar Negeri yang telah memotivasi untuk menulis di buletin ini. Kepada temanteman di Puska daglu dan Pusdatin yang telah memberikan bantuan ketersediaan data dan referensi.

\section{DAFTAR PUSTAKA}

Abramovitz, M. (1986). Catching up, forging ahead, and falling behind. The Journal of Economic History, 46(02), 385-406.

Achsani, N. A., \& H. Siregar. (2010). Classification of the ASEAN+ 3 Economies Using Fuzzy Clustering Approach. European Journal of Scientific Research, 39 (4), 489-497.

Ang, J. B., \& J. B. Madsen. (2013). International R\&D spillovers and productivity trends in the Asian miracle economies. Economic Inquiry, 51(2), 1523-1541.

Bajona, C., \& T. J. Kehoe. (2010). Trade, growth, and convergence in a dynamic Heckscher-Ohlin model. Review of Economic Dynamics, 13 (3), 487-513.

Bank Indonesia. (2014). Laporan Perekonomian Indonesia 2013. Bank Indonesia.

Bernard, A. B., \& S. N. Durlauf. (1996). Interpreting tests of the convergence hypothesis. Journal of Econometrics, 71(1), 161-173.

Boreiko, D. (2002). EMU and Accession Countries: Fuzzy Cluster Analysis of Membership (Working Papers Central Bank of Chile No. 189). Central Bank of Chile. Retrieved from http://ideas.repec. org/p/chb/bcchwp/189.html
Charles, A., O. Darne, \& J.F. Hoarau. (2012). Convergence of real per capita GDP within COMESA countries: A panel unit root evidence. The Annals of Regional Science, 49(1), 53-71. doi:10.1007/ s00168-010-0427-z

Grossman, G. M., \& E. Helpman. (1991). Trade, knowledge spillovers, and growth. European Economic Review, 35(2), 517-526.

Helpman, E. (1981). International trade in the presence of product differentiation, economies of scale and monopolistic competition: A Chamberlin-HeckscherOhlin approach. Journal of International Economics, 11(3), 305-340.

Izakian, H., \& A. Abraham. (2011). Fuzzy C-means and fuzzy swarm for fuzzy clustering problem. Expert Systems with Applications, 38(3), 1835-1838.

Jayanthakumaran, K., \& S. W. Lee. (2013). Evidence on the Convergence of Per Capita Income: A Comparison of Founder Members of the Association of South East Asian Nations and the South Asian Association of Regional Cooperation. Pacific Economic Review, 18(1), 108-121. doi:10.1111/14680106.12013

Krugman, P. R. (1979). Increasing returns, monopolistic competition, and international trade. Journal of International Economics, 9(4), 469-479.

Leamer, E. E., \& J. Levinsohn. (1995). International trade theory: the evidence. Handbook of International Economics, 3, 1339-1394.

Li, H. (2013). Convergence or Divergence?Rethinking Regional Integration of the Past Two Decades. Frontiers of Economics in China, 8(4), 592-607. doi:10.3868/s060-002-013-0030-7

Muslim, A., \& M. Ekananda. (2007). Implementasi Algoritma Cluster Fuzzy dan Neuro-Fuzzy Studi kasus Ekspor Indonesia ke Jepang. Seminar Ekonomi Nasional FEUI Jakarta. 
Nahar, S., \& B. Inder. (2002). Testing convergence in economic growth for OECD countries. Applied Economics, 34(16), 2011-2022.

Romer, D. (2011). Advanced Macroeconomics (4 edition). New York: McGraw-Hill/Irwin.

Sabaruddin, S. S. (2014). The Impact of Indonesia-China Trade Liberalisation on the Welfare of Indonesian Society and on Export Competitiveness. Bulletin of Indonesian Economic Studies, 50(2), 292-293.

Schmitt, C., \& P. Starke. (2011). Explaining convergence of OECD welfare states: a conditional approach. Journal of European Social Policy, 21(2), 120135.

Sjöholm, F. (1999). Productivity growth in Indonesia: the role of regional characteristics and direct foreign investment. Economic Development and Cultural Change, 47(3), 559-584.

Slaughter, M. J. (1998). International trade and per capita income convergence: a difference-in-differences analysis.
National Bureau of Economic Research. Retrieved from http://www.nber.org/ papers/w6557

Stroomer, C., \& D. E. Giles. (2003). Income convergence and trade openness: fuzzy clustering and time series evidence. Department of Economics, University of Victoria, Econometrics Working Paper EWP0304, ISSN, 1485-6441.

Tapia-Herrera, R., J.A. Meda-Campaña, S. Alcántara-Montes, T. HernándezCortés, \& L. Salgado-Conrado. (2013). Tuning of a TS Fuzzy Output Regulator Using the Steepest Descent Approach and ANFIS. Mathematical Problems in Engineering, 2013. Retrieved from http://www.hindawi.com/journals/mpe/ aip/873430/

Wong, B. K., \& V.S. Lai. (2011). A survey of the application of fuzzy set theory in production and operations management: 1998-2009. International Journal of Production Economics, 129(1), 157168.

Zimmermann, H.J. (2010). Fuzzy set theory. Wiley Interdisciplinary Reviews: Computational Statistics, 2(3), 317-332. 
78 Buletin IImiah Litbang Perdagangan, VOL.9 NO.1, JULI 2015 